\title{
CHRONIC INFECTION OF CYSTIC FIBROSIS PATIENT AIRWAYS BY A SINGLE CLONE OF BURKHOLDERIA CEPACIA: REPLACEMENT OF NON-MUCOID TO MUCOID MORPHOTYPE
}

\author{
Ana Paula D'Alincourt Carvalho, ${ }^{1,3}$; Grasiella Maria de Carvalho Ventura' ${ }^{1}$ Tânia Wrobel Folescu ${ }^{2}$; \\ Renato Farme D'Amoed ${ }^{2}$; Laurinda Higa² ${ }^{2}$ Lucia Martins Teixeira³ ; Vânia Lúcia Carreira Merquior'; \\ Elizabeth de Andrade Marques ${ }^{1 *}$
}

\begin{abstract}
${ }^{1}$ Disciplina de Microbiologia e Imunologia, Faculdade de Ciências Médicas, Universidade do Estado do Rio de Janeiro, Rio de Janeiro, RJ, Brasil. ${ }^{2}$ Instituto Fernandes Figueira, Fundação Instituto Oswaldo Cruz, Rio de Janeiro, RJ, Brasil. ${ }^{3}$ Instituto de Microbiologia Prof. Paulo de Góes, Universidade Federal do Rio de Janeiro, Rio de Janeiro, RJ, Brasil.
\end{abstract}

This paper corresponds to an "extended abstract" selected for oral presentation in the $22^{\text {nd }}$ Brazilian Congress of Microbiology, held in Florianópolis, SC, Brazil, in November 17-20, 2003

\begin{abstract}
Mucoid Burkholderia cepacia morphotype emerged within a nine year follow-up of a cystic fibrosis patient. Clinical data suggested a linkage between the mucoid phenotype isolation and the deterioration of the patient's condition. Despite of the phenotypic variation, molecular typing showed that the patient was chronically infected with B. cepacia complex isolates belonging to a same genetic clone.
\end{abstract}

Key words: Cystic Fibrosis, Burkholderia cepacia complex, PFGE, RAPD-PCR.

\section{INTRODUCTION}

Burkholderia cepacia complex has emerged as a major pathogen in patients with Cystic Fibrosis (CF). Multi-drug resistance, cross-infection due to patient to patient transmission or nosocomial spread, and the rapid and unexpected fatal clinical decline (cepacia syndrome) in some patients are factors that have pointed to B. cepacia complex as a major threat to $\mathrm{CF}$ patients $(2,5)$. Mucoid (MUC) morphotype is thought to be relatively rare among $B$. cepacia complex $\mathrm{CF}$ isolates (1). There is no clear data about the possible contribution of the extracellular polysaccharide to the colonization and persistence of the microorganism in the infected host, as was described in patients infected with MUC $P$. aeruginosa (2). This study reports the emergence of a MUC B. cepacia complex morphotype in CF patient chronic infection attended at a reference CF center located in Rio de Janeiro, Brazil.

\section{MATERIALS AND METHODS}

B. cepacia complex isolates were obtained from a CF patient. Since the CF diagnosis, the patient was submitted to a regular multidisciplinary evaluation for nine years (from Nov/1989 to Nov/1998). During this period, 33 sputum samples were obtained and plated onto sheep blood agar, Eugon agar, cystine-lactose-electrolyte-deficient- (CLED) agar and Pseudomonas Isolation agar (Difco Labs, Detroit, MI, USA) added with polimixin $(300 \mu \mathrm{g} / \mathrm{ml})$ (Sigma Co., St Louis, MD, USA). Identification of B. cepacia complex isolates was performed by using biochemical tests (3). Genotyping of MUC and NM B. cepacia complex isolates were performed by PFGE and RAPD-PCR. PFGE was carried out as described previously (8) using $X b a \mathrm{I}$ endonuclease. Banding patterns were visualized by ethidium bromide staining and the profiles were interpreted according to Tenover rules (7). RAPD-PCR was performed as

*Corresponding author. Mailing address: Disciplina de Microbiologia e Imunologia, Faculdade de Ciências Médicas, Universidade do Estado do Rio de Janeiro. Avenida 28 de Setembro, 87/3 ${ }^{\circ}$ andar, Vila Isabel. 20551-030, Rio de Janeiro, RJ, Brasil. E-mail: marbe@uerj.br 
described by Pacheco et al. (6) using primer 1254 (nucleotide sequence 5'-CCGCAGCCAA-3').

\section{RESULTS AND DISCUSSION}

During first six years of the bacteriological follow-up (Nov/ 1989-Nov/1995), S. aureus, NM and MUC P. aeruginosa were the only pathogens detected in the sputa samples. After that, B. cepacia complex was found in association with $P$. aeruginosa for two consecutive years (Dec/1995-Sep/1997). In last year of evaluation (Oct/1997-Nov/1998), MUC $B$. cepacia complex was emerged and persisted chronically as a single pathogen. At the same period, respiratory infection exacerbation had become more frequent and the patient had to be hospitalized at shorter intervals. The computed tomography scanner of the thorax evidenced an increase in bronchiectasis and the pulmonary function test showed a degree II obstructive disturbance.

By both genotypic methods all B. cepacia complex strains shared similar DNA-banding profiles (Figs. 1 and 2) with little variations of one or two bands (Fig. 1 e.g. Lanes 4 and 9). Although, as described previously, strains isolated multiple times from the same patients should demonstrated such variability (7). Molecular typing procedures demonstrated that the patient was chronically infected by a single clone that had remained genetically stable over a period of three years in spite of exopolysaccharide (EPS) expression. Therefore, phenotypic changes in sequential isolates did not represent

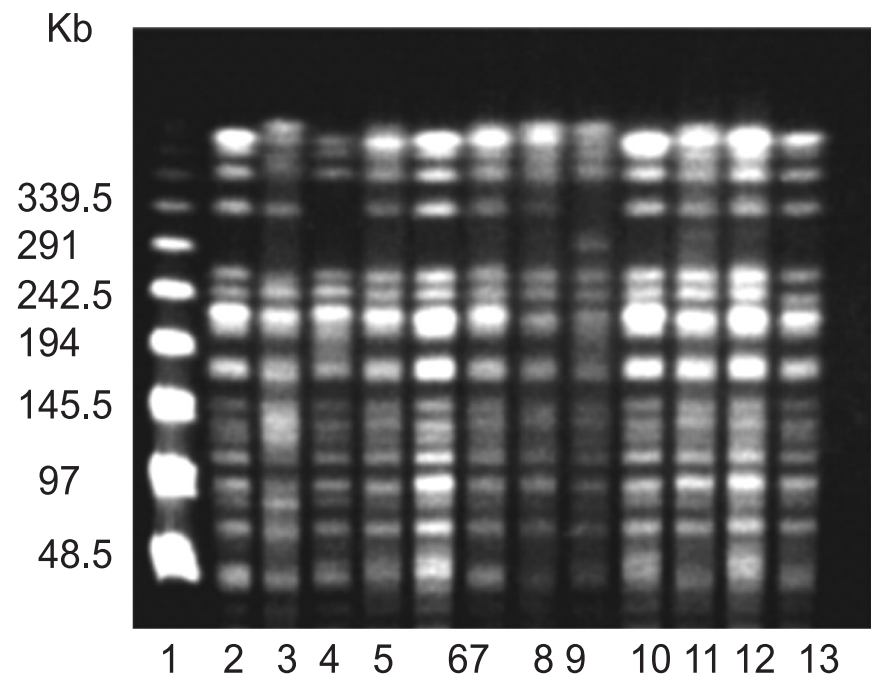

Figure 1. PFGE patterns of chromosomal DNA of sequential Burkholderia cepacia complex isolates after digestion with $X b a I$. Lanes: 1. Molecular size markers (in kilobases); Lanes 2 to 6, non-mucoid B. cepacia complex strains; Lanes 7-13, mucoid B. cepacia complex strains.

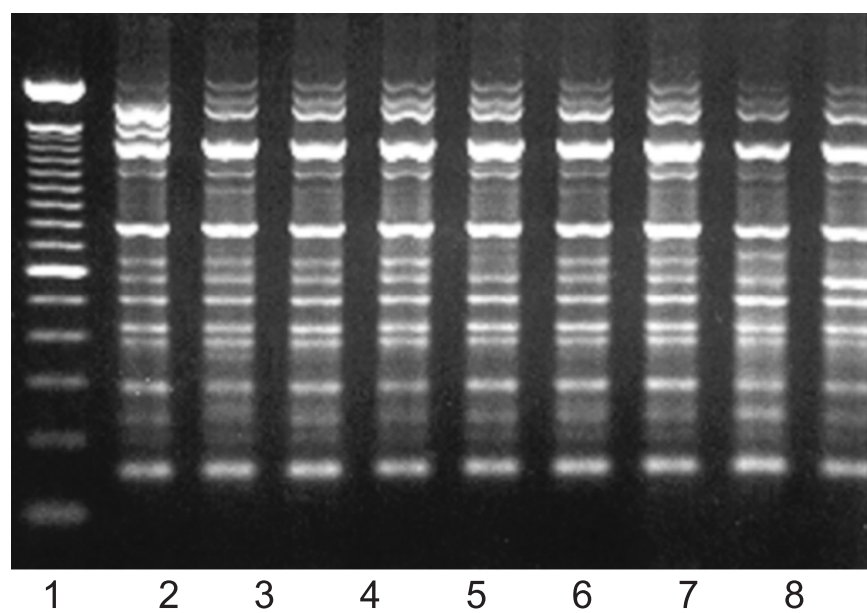

Figure 2. RAPD-PCR profiles of sequential Burkholderia cepacia complex isolates using 1254 primer. Lanes: $1.1 \mathrm{~Kb}$ Ladder (Gibco-BRL); Lanes 2 to 6, non-mucoid B. cepacia complex strains; Lanes 7-10, mucoid B. cepacia complex strains.

replacement by a new strain suggesting an adaptation of the primary colonizing isolates (4). The isolation of MUC $B$. cepacia complex is rare and to the best of our knowledge, the association between the chronic infection of MUC B. cepacia as a single bacterial pathogen with the decline of clinical outcome has not yet been reported. It is essential to evaluate the role of EPS biosynthesis and the possible factors that may lead to the changing of NM to MUC phenotype in the characteristic environment of the lungs of CF patients which could improve our knowledge about B. cepacia complex pathogenesis.

\section{RESUMO}

Infecção pulmonar crônica por um único clone de Burkholderia cepacia: substituição do morfotipo não mucóide por mucóide

O presente trabalho descreve a emergência de cepas mucoides do complexo B. cepacia em um paciente com Fibrose Cística dentro de um acompanhamento bacteriológico prospectivo de nove anos. Os dados clínicos sugerem a associação entre o isolamento do morfotipo mucoide e a deterioração clínica do paciente. Apesar da variação fenotípica, os testes moleculares mostraram que o paciente manteve-se cronicamente infectado por cepas de mesma origem clonal.

Palavras-chave: Fibrose Cística, complexo Burkholderia cepacia, PFGE, RAPD-PCR. 


\section{REFERENCES}

1. Cérantola, S.; Bounéry, J.D.; Segonds, C.; Marty, N.; Montrozier, H. Exopolysaccharide production by mucoid and non-mucoid strains of Burkholderia cepacia. FEMS Microbiol.. Lett., 185:243-246, 2000.

2. Gilligan, P.H. Microbiology of airway disease in patients with cystic fibrosis. Clin. Microbiol. Rev., 4:35-51, 1991.

3. Henry, D.A.; Mahenthiralingam, E.; Vandamme, P.; Coenye, T.; Speert, D.P. Phenotypic methods for determining genomovar status of the Burkholderia cepacia complex. J. Clin. Microbiol., 39:10731078, 2001.

4. Larsen, G.Y.; Stull, T.L.; Burns, J.L. Marked phenotypic variability in Pseudomonas cepacia isolated from a patient with cystic fibrosis. J. Clin. Microbiol., 31:788-792, 1993.

5. Mc Manus, T.E.; Moore, J.E.; Crowe, M.; Dunbar, K.; Elborn, J.S. A comparison of pulmonary exacerbations with single and multiple organisms in patients with cystic fibrosis and chronic Burkholderia cepacia infection. Infection, 46:56-59, 2003.

6. Pacheco, A.B.F.; Guth, B.E.C.; Soares, K.C.C.; Nishimura, L.; Almeida, D.F.; Ferreira, L.C.S. Random amplification of polymorphic DNA reveals serotype-specific clonal clusters among enterotoxigenic Escherichia coli strains isolated from humans. J. Clin. Microbiol., 35:1521-1525, 1997.

7. Tenover, F.C.; Arbet, R.D.; Goering, R.V.; Mickelsen, P.A.; Murray, B.E.; Persing, D.H.; Swaminathan, B. Interpreting chromossomal DNA restriction patterns produced by pulsed-field gel electrophoresis: criteria for bacterial strain typing. J. Clin. Microbiol., 33:2233-239, 1995.

8. Valcin, M.; Moissenet, D.; Sardet, A.; Tournier, G.; Garbac-Chenon, A.; Vu-Thien, H. Pseudomonas (Burkholderia) cepacia in children with cystic fibrosis: Epidemiological investigation by analysis of restriction fragment length polymorphism. Pathol. Biol. (Paris), 44:442-446, 1996. 